\title{
In vitro potency test for evaluation of Clostridium perfringens type $\mathrm{D}$ epsilon toxoid
}

\author{
Avaliação in vitro da potência de toxoide épsilon de \\ Clostridium perfringens tipo D
}

\author{
Felipe Masiero Salvarani ${ }^{1}$, Zélia Ines Portela Lobato ${ }^{1}$, Prhiscylla Sadanã Pires ${ }^{1}$, Rodrigo Otávio \\ Silveira Silva ${ }^{1}$, Guilherme Guerra Alves ${ }^{1}$, Pedro Lúcio Lithg Pereira ${ }^{2}$, Francisco Carlos Faria Lobato ${ }^{1 *}$
}

\begin{abstract}
The control of enterotoxemia caused by the epsilon toxin, produced by Clostridium perfringens type D, is based on vaccination with epsilon toxoid. The potency test for this immunogen is conducted using seroneutralization in mice. Here, an in vitro test for detection of neutralizing antibodies with Madin-Darby Canine Kidney (MDCK) cells was standardized in order to study alternative methodologies for the potency test. Titers observed in the in vivo and in vitro seroneutralization tests had a correlation of $99.73 \%$.
\end{abstract}

KEYWORDS: seroneutralization; mouse; cell culture; bioethics; vaccine.
RESUMO: O controle da enterotoxemia causada pela toxina épsilon produzida por Clostridium perfringens tipo D é baseado na vacinação com toxoide. $\mathrm{O}$ teste de potência desse imunógeno é realizado utilizando-se a técnica de soroneutralização em camundongos. Objetivando-se estudar metodologias alternativas a essa técnica, padronizou-se um teste in vitro para detecção de anticorpos neutralizantes utilizando-se a linhagem celular Madin-Darby Canine Kidney (MDCK). Os títulos observados nas soroneutralizaçóes in vivo e in vitro apresentaram correlação de 99,73\%.

PALAVRAS-CHAVE: soroneutralização; camundongo; cultura de células; bioética; vacina.

This study was conducted according to the ethical principles of animal experimentation established by the Ethics Committee for Animal Experimentation (CETEA/UFMG), protocol n. 40/2008, as determined by the declaration emitted by the Coordinator of the Committee on June 3, 2008.

'Departamento de Medicina Veterinária Preventiva da Escola de Veterinária da Universidade Federal de Minas Gerais (UFMG) - Belo Horizonte (MG), Brazil.

2Departamento de Epidemiologia da Escola de Veterinária da UFMG - Belo Horizonte (MG), Brazil.

*Corresponding author: flobato@vet.ufmg.br

Received on: 12/02/2012. Accepted on: 10/22/2013 
Enterotoxemia is a widespread disease of domestic ruminants caused by epsilon toxin of Clostridium perfringens type $\mathrm{D}$ that results in significant economical losses for the meat and dairy industry (Lовато et al., 2010). The control and prophylaxis are based on good management practices and systematic vaccination. The standard technique proposed by Brazilian legislation for potency tests of clostridial vaccines is seroneutralization (SN) in mice (MAPA, 1997). Despite the known sensitivity and reliability of this potency test in mice, seroneutralization is time-consuming, relatively expensive, and considered ethically debatable by humanitarian groups and researchers aiming to protect animal welfare (METZ et al., 2002).

These bioethical issues have inspired further studies regarding the development of in vitro assays that yield quick, reliable results with good sensitivity and specificity at a decreased cost. Therefore, cell culture methods have been regarded as possible alternatives to $\mathrm{SN}$ in mice (Borrmann et al., 2006). This work aimed to standardize an in vitro $\mathrm{SN}$ test to evaluate the potency of epsilon toxoid and to compare this cell culturebased method to standard animal bioassays.

The production of epsilon toxin was performed as previously described by Azevedo et al. (1998). A standard serum (National Institute for Biological Standards and Control NIBSC, UK) with $10 \mathrm{IU} / \mathrm{mL}$ of anti-epsilon toxin antibodies was used for epsilon-toxin standardization. Test sera used in both the in vitro and in vivo SN were obtained from pools of rabbits immunized with clostridial vaccines containing epsilon toxoid and standard serum with different concentrations. Negative control rabbits were inoculated with $0.85 \%$ saline solution under the same conditions. These test sera were titrated in mice according to Lobato et al. (2000) at the L+/10 level (British Pharmacopeia, 1998). The use of animals in this study was approved by the Ethics Committee for Animal Experimentation (CETEA), Federal University of Minas Gerais, no 40/2008. The cell line used was MadinDarby Canine Kidney (MDCK - ATCC/CCL-34) cultivated in Eagle's minimum essential medium (EMEM - Gibco Laboratories, USA; SouZA JÚNIOR et al., 2010).

The epsilon toxin was standardized in vitro to the test level $\mathrm{L}+/ 50$. Titration of the test sera was performed in 96 wells plates. Four repetitions of two-fold serial dilutions from 1:2.5 to 1:320 were prepared to a final volume of $50 \mu \mathrm{L} /$ well. Another $50 \mu \mathrm{L}$ was then added to each well containing standardized toxin at the test level $\mathrm{L}_{+} / 50$. The plates were homogenized, re-incubated, and cellular suspensions $\left(4.8 \times 10^{4}\right.$ cells $\left./ 50 \mu \mathrm{L}\right)$ were added. Positive control wells contained $50 \mu \mathrm{L}$ of standardized toxin, $50 \mu \mathrm{L}$ of EMEM, and $50 \mu \mathrm{L}$ of cells. Negative control wells had $100 \mu \mathrm{L}$ of EMEM and $50 \mu \mathrm{L}$ of cells. Serum control wells had $50 \mu \mathrm{L}$ of the test serum, $50 \mu \mathrm{L}$ of EMEM, and $50 \mu \mathrm{L}$ of cells. The plate was incubated at $37^{\circ} \mathrm{C}$ in a humid chamber (Sheldon Manufacturing Inc - Oregon, USA) with a controlled atmosphere $\left(5 \% \mathrm{CO}_{2}\right.$ and $\left.95 \% \mathrm{O}_{2}\right)$ for 48 hours. The supernatant was removed after this period. Staining was done with $100 \mu \mathrm{L}$ of crystal violet solution $(0.1 \%$ in alcohol $)$ to observe the cytopathic effect (CPE) (SouzA JúNIOR et al., 2010). Titers of the test sera were calculated as the highest dilution, resulting in $70 \%$ destruction of the cell monolayer (KNight et al., 1990). Retrotitration with standard antitoxin was used to check the standardization of the toxin (SALVARANi et al., 2010). Results of in vivo and in vitro SN were analyzed and compared with a parametrical correlation using Pearson's correlation (Sampaio, 1998).

The results of in vivo and in vitro $\mathrm{SN}$ are shown in Table 1.

Titers obtained by in vitro SN were within intervals of the in vivo $\mathrm{SN}$ titers. The correlation between the results was $99.73 \%(\mathrm{p}<0.05)$, which was superior to the $91 \%$ previously demonstrated by KNIGHT et al. (1990). In vitro repeatability was $99.97 \%$. Similar results were also previously reported by Salvarani et al. (2010) and Lima et al. (2011), which reported a correlation greater than $98 \%$ for alpha toxin of Clostridium septicum and for alpha toxin of Clostridium novyi type B, respectively. The viability of substituting the animal bioassay with in vitro models is thus proved.

Cell culture has a number of advantages over the animal bioassays. These include a significant decrease in the number of animals utilized, greater sensitivity and lower variation among individual responses. Additionally, an in vitro model that indicates cytotoxicity allows for the observation and study of the biological activity of the epsilon toxin, which is not attainable through other in vitro techniques such as ELISA and agar gel immunodiffusion.

This study demonstrates that detection of anti-epsilontoxin by in vitro $\mathrm{SN}$ in MDCK cells is a viable option to replace the animal bioassays that are typically utilized in potency tests for clostridial vaccines containing epsilon toxoid.

This work was supported by Conselho Nacional de Desenvolvimento Científico e Tecnológico (CNPq), Fundação de Amparo à Pesquisa do Estado de Minas Gerais (FAPEMIG) and Instituto Nacional de Ciência e Tecnologia - Informação Genético Sanitária da Pecuária Brasileira. FCFL was supported by fellowship from CNPq (Brasília, Brazil).

Table 1. Titers $(\mathrm{IU} / \mathrm{mL})$ of anti-epsilon-toxin in serum pool of vaccinated rabbits and standard serum obtained by seroneutralization in the mouse and MDCK cells.

\begin{tabular}{lcc}
\multirow{2}{*}{ Serum } & \multicolumn{2}{c}{ Antibody titer $(\mathrm{IU} / \mathrm{mL})$} \\
\cline { 2 - 3 } T1 & Mouse & Cells \\
\hline T2 & 12.0 & 11.3 \\
\hline T3 & 6.0 & 5.6 \\
\hline T4 & 4.0 & 3.8 \\
\hline T5 & 10.0 & 10.2 \\
\hline T6 & 90.0 & 90.4 \\
\hline T7 (negative control) & 180.0 & 180.8 \\
\hline
\end{tabular}

ND: not detectable. 


\section{REFERENCES}

AZEVEDO, E.O.; LOBATO, F.C.F.; ABREU, V.L.V.; MAIA, J.D.; NASCIMENTO, R.A. Avaliação de vacinas contra Clostridium perfringens tipos C e D. Arquivo Brasileiro de Medicina Veterinária e Zootecnia, v.50, p.239-242, 1998.

BORRMANN, E.; SCHULZE, F.; CUSSLER, K.; HÄNEL, I.; DILLER, $R$. Development of a cell culture assay for the quantitative determination of vaccination-induced antibodies in rabbit sera against Clostridium perfringens epsilon toxin and Clostridium novyi alpha toxin. Veterinary Microbiology, v. 1 14, p.41-50, 2006.

BRITISH PHARMACOPEIA. Veterinary Antisera and Veterinary Vaccines. 3.ed. Sainte Ruffine: Maisonneuve S.A., 1998.

KNIGHT, P.A.; QUEMINET, J.; BLANCHARD, J.H.; TILLERAY, J.H. In vitro tests for the measurement of clostridial toxins, toxoids and antisera. II. Titration of Clostridium perfringens toxins and antitoxins in cell culture. Biologicals, v.18, n.4, p.263-270, 1990.

LIMA, C.G.R.D.; LOBATO, Z.I.P.; PIRES, P.S.; SILVA, R.O.S.; SALVARANI, F.M.; ASSIS, R.A.; LOBATO, F.C.F. Padronização de teste de potência in vitro para vacinas que contenham toxoide alfa de Clostridium novyi tipo B. Revista Arquivos do Instituto Biológico, v.78, n.4, p.507-512, 2011.

LOBATO, F.C.F.; MORO, E.; UMEHARA, O.; ASSIS, R.A.; MARTINS, N.E.; GONÇALVES, L.C.B. Avaliação da resposta de antitoxinas beta e épsilon de Clostridium perfringens induzidas em bovinos e coelhos por seis vacinas comerciais no Brasil. Arquivo Brasileiro de Medicina Veterinária e Zootecnia, v.52, n.4, p.313-318, 2000.
LOBATO, F.C.F.; LIMA, C.G.R.D.; ASSIS, R.A.; PIRES, P.S.; SILVA, R.O.S.; SALVARANI, F.M.; CARMO, A.O.; CONTIGLI, C.; KALAPHOTAKIS, E. Potency against enterotoxemia of a recombinant Clostridium perfringens type $D$ epsilon toxoid in ruminants. Vaccine, v.28, n.38, p.6125-6127, 2010.

MAPA - MINISTÉRIO DA AGRICULTURA, PECUÁRIA E ABASTECIMENTO. Portaria n 49, de 12 de maio de 1997. Diário Oficial da União. Brasília, 16 de maio de 1997. Seção 1.

METZ, B.; HENDRIKSEN, C.F.; JISKOOT, W.; KERSTEN, G.F. Reduction of animal use in human vaccine quality control: opportunities and problems. Vaccine, v.20, n.19, p.2411-2430, 2002.

SALVARANI, F.M.; LOBATO, Z.I.P.; ASSIS, R.A.; LIMA, C.G.R.D.; SILVA, R.O.S.; PIRES, P.S.P.; LOBATO, F.C.F. In vitro evaluation of the alpha toxoid from Clostridium septicum. Arquivo Brasileiro de Medicina Veterinária e Zootecnia, v.62, n.4, p.778-783, 2010.

SAMPAIO, I.B.M. Estatística aplicada à experimentação animal. Belo Horizonte: Fundação de Ensino e Pesquisa em Medicina Veterinária e Zootecnia, 1998.

SOUZA JÚNIOR, M.F.; LOBATO, Z.I.P.; PIRES, P.S.; SILVA, R.O.S.; SALVARANI, F.M.; ASSIS, R.A.; LOBATO, F.C.F. Padronização da titulação da toxina épsilon de Clostridium perfringens tipo $D$ em linhagem contínua de células como alternativa ao bioensaio animal. Ciência Rural, v.40, n.3, p.600-603, 2010. 